\title{
Creative Marketing as an Approach for Acquiring Competitive Advantage for Sports Clubs
}

\author{
Ehab Mohamed Khairy ${ }^{*}$
}

\begin{abstract}
The current research aims to identify the role of creative marketing in acquiring competitive advantage for sports clubs. The researcher used the descriptive (survey) approach. Research community included board members, general managers, directors and officials of marketing departments, beneficiaries from outside the clubs and club members of major sports clubs (Al-Ahly - Al-Zamalek - Al-Ismaeely - Al-Ettihad Al-Sakandary - Al-Mahalla - Al-Mansoura - Al-Mesry). The researcher chose (150) persons as a main sample and another (30) persons as a pilot sample. Results indicated that:
\end{abstract}

- Sports clubs use creative marketing as a permanent strategy

- Sports clubs plan for marketing o the short and long run

- Sports clubs create new markets

- Sports clubs are interested in contracting with international clubs and companies as a source of creativity

- Sports clubs consider quality standards of sports products

- Sports clubs perform research studies through their marketing departments

- Sports clubs use modern technology in product delivery

- The organizational structure of the creative marketing in the club should be as an integrated team

Key words: creative marketing - competitive advantage - sports clubs

\section{Research Problem:}

Recently, competitive advantage has gained global interest as a response to quick developments resulting from globalization, merged world economy, openness and free market policies in addition to major advances in information and communication technology. All these variables make it difficult for any country to stay away from such advances (39:23).

The major task of marketing is to facilitate the flow of goods and services during sports events from production centers (sports associations) to buying centers. Al-Mogy, K. (2002) and Darwish, K. \& Hasanain, M. (2004) indicated that sport has become a global economic system. In addition, it has become a valuable commodity and a well-established industry. It is now a major field of business. Commodities include equipment, distinct athletic product (athlete - referee administrator - coach - facility) and events that gather together all these basic pillars of marketing. This clearly indicates the role of sport in investment and profit making through sports marketing (14: 3) (19: 91).

Therefore, sports administration should face such challenges and variables scientifically through finding out non-traditional ways of self-finance and marketing in sport. Chourides et al (2003) indicated that competition among producers or among economic systems has moves from mere competition during production to a fierce competition during thinking, renovation and creativity. Therefore, organization's success, continuity, growth and stability depend on adopting the spirit of renovation and creativity in all its activities. This means to insure a continuous flow of new and well-developed commodities, modern methods of production and baking in addition to modern methods for marketing (18: 217).

\footnotetext{
${ }^{*}$ Lecturer, Department of Sports Administration - Faculty of Physical Education - Tanta University
} 
Vanheerde \& Mela (2004) indicated that creativity is the key to competitive advantage as it affects reshaping the industry and leads to quick obsolescence of strategies. This, in turn, leads to new rules of competition and market entry/exit (51: 87).

There is no doubt that creative marketing is of major importance for both organizations and clients. For organizations using creative marketing, they can achieve competitive advantage over competitors through creating a competitive image, reputation and other aspects of competitive advantage. It is clear that competitive advantage has positive effects including maintenance or even increasing the organization's market share, increasing sales and profits and gaining the leading position of the market (with all its benefits). In addition, it enables the organization to sustain new clients and maintain old ones. Finding and maintaining competitive advantage for as long as possible through creative marketing means that the organization may be able to gain the profits of this type of marketing. Competitive advantage is not the ultimate goal in itself. Instated, it is how to maintain it longer that matters.

The major challenge facing Egyptian sports clubs is clear in its need for developing competitive abilities on the national and international levels. The main cause of success for major international sports clubs is introducing creative products and marketing them creatively. Sports clubs need not only to know what its members and clients desire now, but also to predict their future needs and desires. Discovering new marketing trends increases the club's ability to look carefully the future. This provides clubs with required time for mobilizing necessary and required resources to develop ideas, processes and products.

Several studies dealt with creative marketing like Abu Gomaa, N. (2000), Abu AlNaga, A. (2008), Haddad, S. \& Al-Ghadeer, H. (2004), Atia, M. (2005), Anonymous (2005), Schiele, H. (2006), Maddever, M. (2005), Atia, M. (2010), Ioakimidis (2010), Rady et al (2010), Radikonyana (2013), Radwan et al (2013) and Mafini \& Shurup (2014). These studies indicated that creativity is considered as an administrative function just like planning, organization, direction and monitoring. Creative marketing is not an alternative for traditional marketing. Instead, they are integral. Administrators in sports clubs and sports federations should be aware of creative marketing. There should be a specialized department for sports marketing in clubs due to the lack of qualified and experienced specialists in finance and sports marketing. Other authors like Abu Al-Naga, A. (2008) and Ghanbari \& Saboonchi (35) dealt with competitive advantage. They indicated a directly proportionate relation between the concept of creativity adopted by organizations in their marketing activities and their competitive position among other organizations. They also indicated the relation between the creative markting mix and achieving competitive advantage. Furthermore, they stated that organizations adopting technology and e-administration methods gain the full fruit of competitive advantage. (6) (5) (28) (48) (37) (17) (32) (43) (42) (45) (38) (25).

A sports club can create a competitive advantage but competitors quickly imitate it and therefore it vanishes quickly. This depends on resources and capabilities used in building this competitive advantage. The competitive advantage stays longer when its resources and capabilities are hard to imitate. Therefore, it should depend on various resources and capabilities so that it is difficult to identify the reasons of competitive advantage and how to imitate it. In addition, the club should seek a new advantage as an alternative for the one that is almost obsolete. Innovation and creativity are the main pillars for competitive advantage. Innovation is not limited to developing the product or service. Instead, it includes innovative strategies, innovative technologies and processes and innovative creation of value-add for the clubs' products.

Creativity is the backbone of marketing. Sports clubs, especially major ones, should work on creating distinctive feature nationally and internationally to assure their competitiveness, advance and continuity. Innovative and creative marketing are very 
-3 -

important for renovating and introducing new products and services. They are considered as modern marketing methods away from traditional marketing. Therefore, the researcher is trying to identify the extent to which creative marketing can lead to competitive advantage for major sports clubs.

Aim:

The current research aims to identify the role of creative marketing in acquiring competitive advantage for sports clubs.

\section{Research Questions:}

- What is the role of creative marketing concept?

- What is the role of signing contracts among sports clubs and international companies as a source of creativity?

- What is role of creative product?

- What is the role of creative distribution?

- What is the role of creative promotion?

- What is the role of creative pricing?

- What is the role of creative communication?

- What is the role of higher administration in supporting creative marketing?

- What is the role of creative marketing in achieving competitive advantage?

\section{Materials \& Methods:}

Approach:

The researcher used the descriptive (survey) approach.

\section{Participants:}

Research community included board members, general managers, directors and officials of marketing departments, beneficiaries from outside the clubs and club members of major sports clubs (Al-Ahly - Al-Zamalek - Al-Ismaeely - Al-Ettihad Al-Sakandary - AlMahalla - Al-Mansoura - Al-Mesry). The researcher chose (150) persons as a main sample and another (30) persons as a pilot sample.

Table (1): Descriptive Data of Participants

\begin{tabular}{l|c|c|c}
\hline \multicolumn{1}{c|}{ Division } & Community & Pilot sample & Main sample \\
\hline Board members - general managers & 60 & 10 & 50 \\
\hline Managers and officials of marketing departments & 30 & 5 & 25 \\
\hline Beneficiaries from outside the clubs & 30 & 5 & 25 \\
\hline Club members & 60 & 10 & 50 \\
\hline Total & 180 & 30 & 150 \\
\hline
\end{tabular}

Data collection tools:

The researcher designed a questionnaire according to the following steps:

1. Review of related literature

2. Identifying axes of the questionnaire

3. Formulating items of the questionnaire

4. Presenting the preliminary version to (10) experts of general administration, business administration and sports administration to identify their opinions about:

- The suitability of axes

- The close relation among items and axes

- The objectivity of items

Validity of the Questionnaire:

\section{Content validity:}

The researcher used judges' validity to identify the suitability of items with axes. According to experts' opinions, some items were modified or eliminated. 
Table (2): Frequency, percentage and relative importance of experts' opinions about the axes of creative marketing questionnaire $(n=10)$

\begin{tabular}{|c|c|c|c|c|c|c|}
\hline \multirow{2}{*}{ Axis } & \multicolumn{2}{|c|}{ Agree } & \multicolumn{2}{|c|}{ Disagree } & \multirow{2}{*}{$\begin{array}{l}\text { Relative } \\
\text { weight }\end{array}$} & \multirow{2}{*}{$\begin{array}{l}\text { Relative } \\
\text { importance }\end{array}$} \\
\hline & $\mathrm{F}$ & $\%$ & $\mathrm{~F}$ & $\%$ & & \\
\hline creative marketing concept & 10 & 100 & - & 00.00 & 10 & 100 \\
\hline $\begin{array}{l}\text { Importance of signing contracts among sports clubs and } \\
\text { international companies as a source of creativity }\end{array}$ & 9 & 90 & 1 & 10 & 9 & 90 \\
\hline creative product & 10 & 100 & - & 0.00 & 10 & 100 \\
\hline creative distribution & 10 & 100 & - & 0.00 & 10 & 100 \\
\hline creative promotion & 10 & 100 & - & 0.00 & 10 & 100 \\
\hline creative pricing & 10 & 100 & - & 0.00 & 10 & 100 \\
\hline creative communication & 8 & 80 & 2 & 20 & 8 & 80 \\
\hline $\begin{array}{l}\text { the role of higher administration in supporting creative } \\
\text { marketing }\end{array}$ & 10 & 100 & - & 0.00 & 10 & 100 \\
\hline $\begin{array}{l}\text { the role of creative marketing in achieving competitive } \\
\text { advantage }\end{array}$ & 10 & 100 & - & 0.00 & 10 & 100 \\
\hline
\end{tabular}

Table (2) indicated that experts' agreement percentage ranged from $80 \%$ to $100 \%$. All axes reaching $80 \%$ or more of agreement were included.

Table (3): Preliminary and final count of items and numbers of excluded items of the

\begin{tabular}{l|c|c|c|c|c|c}
\hline Axis & $\begin{array}{c}\text { Preliminary } \\
\text { count }\end{array}$ & $\begin{array}{c}\text { Sum of } \\
\text { excluded } \\
\text { items }\end{array}$ & $\begin{array}{c}\text { Numbers of } \\
\text { excluded items }\end{array}$ & $\begin{array}{c}\text { Sum of } \\
\text { modified } \\
\text { items }\end{array}$ & $\begin{array}{c}\text { Numbers of } \\
\text { modified items }\end{array}$ & $\begin{array}{c}\text { Final } \\
\text { count }\end{array}$ \\
\hline 1 & 12 & 1 & 12 & 2 & $1-2$ & 11 \\
\hline 2 & 15 & 2 & $3-7$ & 0 & 0 & 13 \\
\hline 3 & 17 & 0 & 0 & 0 & 0 & 17 \\
\hline 4 & 14 & 0 & 0 & 0 & 0 & 14 \\
\hline 5 & 13 & 1 & 5 & 1 & 0 & 12 \\
\hline 6 & 18 & 1 & 0 & 0 & 0 & 18 \\
\hline 7 & 13 & 1 & 2 & 0 & 0 & 12 \\
\hline 8 & 16 & 0 & 3 & 1 & 13 & 15 \\
\hline 9 & 16 & 6 & 0 & 4 & & 16 \\
\hline Total & 134 & 6 & & & & 128 \\
\hline
\end{tabular}

Table (3) shows the preliminary and final counts of questionnaire items. 
Internal consistency:

Table (4): Internal consistency between each item and its axis and each item and total score of the questionnaire $(n=30)$

\begin{tabular}{|c|c|c|c|c|c|c|c|c|c|c|c|c|c|c|}
\hline \multicolumn{3}{|c|}{ First axis } & \multicolumn{3}{|c|}{ Second axis } & \multicolumn{3}{|c|}{ Third axis } & \multicolumn{3}{|c|}{ Fourth axis } & \multicolumn{3}{|c|}{ Fifth axis } \\
\hline Item & $\begin{array}{l}\text { Item } \\
\text { with } \\
\text { axis } \\
\end{array}$ & $\begin{array}{l}\text { Item } \\
\text { with } \\
\text { total }\end{array}$ & Item & $\begin{array}{l}\text { Item } \\
\text { with } \\
\text { axis }\end{array}$ & $\begin{array}{l}\text { Item } \\
\text { with } \\
\text { total }\end{array}$ & Item & $\begin{array}{l}\text { Item } \\
\text { with } \\
\text { axis }\end{array}$ & $\begin{array}{l}\text { Item } \\
\text { with } \\
\text { total }\end{array}$ & Item & $\begin{array}{l}\text { Item } \\
\text { with } \\
\text { axis }\end{array}$ & $\begin{array}{l}\text { Item } \\
\text { with } \\
\text { total }\end{array}$ & Item & $\begin{array}{l}\text { Item } \\
\text { with } \\
\text { axis }\end{array}$ & $\begin{array}{l}\text { Item } \\
\text { with } \\
\text { total }\end{array}$ \\
\hline 1 & 0.84 & 0.88 & 1 & 0.75 & 0.82 & 1 & 0.75 & 0.82 & 1 & 0.86 & 0.90 & 1 & 0.86 & 0.81 \\
\hline 2 & 0.80 & 0.89 & 2 & 0.84 & 0.91 & 2 & 0.82 & 0.88 & 2 & 0.88 & 0.83 & 2 & 0.90 & 0.84 \\
\hline 3 & 0.89 & 0.84 & 3 & 0.63 & 0.70 & 3 & 0.77 & 0.82 & 3 & 0.70 & 0.67 & 3 & 0.89 & 0.81 \\
\hline 4 & 0.77 & 0.72 & 4 & 0.78 & 0.84 & 4 & 0.68 & 0.74 & 4 & 0.85 & 0.91 & 4 & 0.84 & 0.90 \\
\hline 5 & 0.86 & 0.91 & 5 & 0.79 & 0.73 & 5 & 0.79 & 0.73 & 5 & 0.68 & 0.76 & 5 & 0.85 & 0.91 \\
\hline 6 & 0.68 & 0.74 & 6 & 0.78 & 0.71 & 6 & 0.82 & 0.78 & 6 & 0.87 & 0.92 & 6 & 0.76 & 0.83 \\
\hline 7 & 0.85 & 0.85 & 7 & 0.88 & 0.84 & 7 & 0.91 & 0.87 & 7 & 0.73 & 0.84 & 7 & 0.87 & 0.92 \\
\hline 8 & 0.89 & 0.82 & 8 & 0.92 & 0.89 & 8 & 0.74 & 0.79 & 8 & 0.92 & 0.86 & 8 & 0.77 & 0.84 \\
\hline 9 & 0.68 & 0.75 & 9 & 0.81 & 0.79 & 9 & 0.86 & 0.92 & 9 & 0.87 & 0.92 & 9 & 0.86 & 0.82 \\
\hline 10 & 0.81 & 0.79 & 10 & 0.86 & 0.91 & 10 & 0.83 & 0.90 & 10 & 0.89 & 0.84 & 10 & 0.84 & 0.89 \\
\hline 11 & 0.78 & 0.83 & 11 & 0.90 & 0.85 & 11 & 0.90 & 0.86 & 11 & 0.92 & 0.88 & 11 & 0.74 & 0.78 \\
\hline & & & 12 & 0.92 & 0.86 & 12 & 0.73 & 0.78 & 12 & 0.86 & 0.91 & 12 & 0.90 & 0.83 \\
\hline & & & 13 & 0.89 & 0.83 & 13 & 0.85 & 0.91 & 13 & 0.80 & 0.89 & & & \\
\hline & & & & & & 14 & 0.66 & 0.72 & 14 & 0.89 & 0.84 & & & \\
\hline & & & & & & 15 & 0.74 & 0.83 & & & & & & \\
\hline & & & & & & 16 & 0.82 & 0.77 & & & & & & \\
\hline & & & & & & 17 & 0.81 & 0.76 & & & & & & \\
\hline
\end{tabular}

Table (4) (Continued)

\begin{tabular}{|c|c|c|c|c|c|c|c|c|c|c|c|}
\hline \multicolumn{3}{|c|}{ Sixth axis } & \multicolumn{3}{|c|}{ Seventh axis } & \multicolumn{3}{|c|}{ Eighth axis } & \multicolumn{3}{|c|}{ Ninth axis } \\
\hline Item & $\begin{array}{l}\text { Item with } \\
\text { axis }\end{array}$ & $\begin{array}{c}\text { Item with } \\
\text { total }\end{array}$ & Item & $\begin{array}{l}\text { Item with } \\
\text { axis }\end{array}$ & $\begin{array}{c}\text { Item with } \\
\text { total }\end{array}$ & Item & $\begin{array}{l}\text { Item with } \\
\text { axis }\end{array}$ & $\begin{array}{c}\text { Item with } \\
\text { total }\end{array}$ & Item & $\begin{array}{l}\text { Item with } \\
\text { axis }\end{array}$ & $\begin{array}{c}\text { Item with } \\
\text { total }\end{array}$ \\
\hline 1 & 0.91 & 0.88 & 1 & 0.87 & 0.92 & 1 & 0.91 & 0.87 & 1 & 0.84 & 0.80 \\
\hline 2 & 0.71 & 0.78 & 2 & 0.90 & 0.86 & 2 & 0.74 & 0.79 & 2 & 0.68 & 0.63 \\
\hline 3 & 0.83 & 0.90 & 3 & 0.87 & 0.92 & 3 & 0.82 & 0.77 & 3 & 0.90 & 0.83 \\
\hline 4 & 0.75 & 0.82 & 4 & 0.73 & 0.84 & 4 & 0.81 & 0.76 & 4 & 0.89 & 0.81 \\
\hline 5 & 0.82 & 0.88 & 5 & 0.88 & 0.78 & 5 & 0.86 & 0.90 & 5 & 0.82 & 0.87 \\
\hline 6 & 0.87 & 0.82 & 6 & 0.78 & 0.83 & 6 & 0.88 & 0.83 & 6 & 0.89 & 0.81 \\
\hline 7 & 0.83 & 0.88 & 7 & 0.92 & 0.86 & 7 & 0.89 & 0.84 & 7 & 0.91 & 0.86 \\
\hline 8 & 0.86 & 0.81 & 8 & 0.77 & 0.82 & 8 & 0.92 & 0.88 & 8 & 0.87 & 0.91 \\
\hline 9 & 0.90 & 0.84 & 9 & 0.68 & 0.74 & 9 & 0.90 & 0.86 & 9 & 0.86 & 0.92 \\
\hline 10 & 0.85 & 0.91 & 10 & 0.79 & 0.73 & 10 & 0.73 & 0.78 & 10 & 0.82 & 0.87 \\
\hline 11 & 0.76 & 0.83 & 11 & 0.82 & 0.78 & 11 & 0.85 & 0.91 & 11 & 0.88 & 0.92 \\
\hline 12 & 0.88 & 0.92 & 12 & 0.92 & 0.87 & 12 & 0.74 & 0.83 & 12 & 0.79 & 0.73 \\
\hline 13 & 0.91 & 0.86 & & & & 13 & 0.82 & 0.77 & 13 & 0.90 & 0.86 \\
\hline 14 & 0.87 & 0.92 & & & & 14 & 0.85 & 0.91 & 14 & 0.88 & 0.91 \\
\hline 15 & 0.77 & 0.84 & & & & 15 & 0.90 & 0.84 & 15 & 0.78 & 0.83 \\
\hline 16 & 0.82 & 0.76 & & & & & & & 16 & 0.89 & 0.81 \\
\hline 17 & 0.75 & 0.70 & & & & & & & & & \\
\hline 18 & 0.84 & 0.90 & & & & & & & & & \\
\hline
\end{tabular}

Table (4) indicated statistically significant correlations between each item and its axis and each item and total score. This proves the internal consistency of the questionnaire.

Table (5): Correlation coefficients between each axis and total score of the questionnaire $(\mathbf{n}=\mathbf{3 0})$

\begin{tabular}{c|c}
\hline Axis & Correlation coefficient \\
\hline 1 & 0.89 \\
\hline 2 & 0.82 \\
\hline 3 & 0.80 \\
\hline 4 & 0.79 \\
\hline 5 & 0.91 \\
\hline 6 & 0.78 \\
\hline 7 & 0.86 \\
\hline 8 & 0.88 \\
\hline 9 & \\
\hline
\end{tabular}

Table (5) indicated statistically significant correlations between each axis and total score. This proves the internal consistency of the questionnaire. 
Reliability of the questionnaire:

Table (6): Correlation Coefficient between test and retest of the questionnaire $(n=30)$

\begin{tabular}{|c|c|c|c|c|c|c|c|c|c|c|c|c|c|c|c|c|c|}
\hline \multicolumn{2}{|c|}{ Axis 1} & \multicolumn{2}{|c|}{ Axis 2} & \multicolumn{2}{|c|}{ Axis 3} & \multicolumn{2}{|r|}{ Axis 4} & \multicolumn{2}{|c|}{ Axis 5} & \multicolumn{2}{|c|}{ Axis 6} & \multicolumn{2}{|c|}{ Axis 7} & \multicolumn{2}{|c|}{ Axis 8} & \multicolumn{2}{|c|}{ Axis 9} \\
\hline Item & R & Item & $\bar{R}$ & Item & $\bar{R}$ & Item & $\bar{R}$ & Item & R & Item & R & Item & R & Item & R & Item & R \\
\hline 1 & 0.72 & 1 & 0.91 & 1 & 0.9 & 1 & 0.87 & 1 & 0.86 & 1 & \begin{tabular}{|l|}
0.9 \\
\end{tabular} & 1 & 0.89 & 1 & 0.91 & 1 & 0.89 \\
\hline 2 & 0.86 & 2 & 0.87 & 2 & 0.86 & 2 & 0.89 & 2 & 0.83 & 2 & 0.86 & 2 & 0.92 & 2 & 0.87 & 2 & 0.86 \\
\hline 3 & 0.74 & 3 & 0.84 & 3 & \begin{tabular}{|l|}
0.75 \\
\end{tabular} & 3 & 0.87 & 3 & 0.87 & 3 & 0.88 & 3 & 0.85 & 3 & 0.86 & 3 & 0.91 \\
\hline 4 & 0.87 & 4 & 0.68 & 4 & \begin{tabular}{|l|}
0.88 \\
\end{tabular} & 4 & 0.69 & 4 & 0.73 & 4 & 0.85 & 4 & 0.84 & 4 & 0.91 & 4 & 0.73 \\
\hline 5 & 0.75 & 5 & 0.9 & 5 & 0.86 & 5 & 0.87 & 5 & 0.92 & 5 & 0.91 & 5 & 0.87 & 5 & 0.83 & 5 & 0.84 \\
\hline 6 & 0.92 & 6 & 0.88 & 6 & \begin{tabular}{|l|}
0.91 \\
\end{tabular} & 6 & 0.89 & 6 & 0.72 & 6 & 0.88 & 6 & 0.86 & 6 & 0.89 & 6 & 0.89 \\
\hline 7 & 0.84 & 7 & 0.84 & 7 & \begin{tabular}{|l|}
0.84 \\
\end{tabular} & 7 & 0.91 & 7 & 0.89 & 7 & 0.69 & 7 & 0.69 & 7 & 0.85 & 7 & 0.86 \\
\hline 8 & 0.72 & 8 & 0.89 & 8 & \begin{tabular}{|l|}
0.75 \\
\end{tabular} & 8 & 0.67 & 8 & 0.84 & 8 & 0.84 & 8 & 0.85 & 8 & 0.69 & 8 & 0.91 \\
\hline 9 & 0.87 & 9 & 0.86 & 9 & \begin{tabular}{|l|}
0.89 \\
\end{tabular} & 9 & 0.87 & 9 & 0.89 & 9 & 0.91 & 9 & 0.67 & 9 & 0.85 & 9 & 0.83 \\
\hline 10 & 0.9 & 10 & 0.84 & 10 & \begin{tabular}{|l|}
0.91 \\
\end{tabular} & 10 & 0.72 & 10 & 0.86 & 10 & 0.73 & 10 & 0.82 & 10 & 0.84 & 10 & 0.89 \\
\hline \multirow[t]{8}{*}{11} & 0.76 & 11 & 0.9 & 11 & \begin{tabular}{|l|}
0.73 \\
\end{tabular} & 11 & 0.91 & 11 & 0.85 & 11 & 0.85 & 11 & & 11 & 0.9 & 11 & 0.9 \\
\hline & & 12 & 0.76 & 12 & \begin{tabular}{|l|}
0.84 \\
\end{tabular} & 12 & 0.85 & 12 & 0.91 & 12 & 0.87 & 12 & & 12 & 0.76 & 12 & 0.86 \\
\hline & & 13 & 0.89 & 13 & \begin{tabular}{|l|}
0.68 \\
\end{tabular} & 13 & 0.64 & & & 13 & 0.69 & & & 13 & 0.89 & 13 & 0.88 \\
\hline & & & & 14 & \begin{tabular}{|l|}
0.87 \\
\end{tabular} & 14 & 0.75 & & & 14 & 0.73 & & & 14 & 0.9 & 14 & 0.85 \\
\hline & & & & 15 & 0.91 & & & & & 15 & 0.82 & & & 15 & 0.86 & 15 & 0.86 \\
\hline & & & & 16 & 0.83 & & & & & 16 & 0.77 & & & & 0.75 & 16 & 0.84 \\
\hline & & & & 17 & 0.89 & & & & & 17 & 0.87 & & & & & & \\
\hline & & & & & & & & & & 18 & 0.84 & & & & & & \\
\hline
\end{tabular}

Table (5) indicated statistically significant correlations between test and retest as correlation coefficients ranged between (0.64) and (0.92). This proves the reliability of the questionnaire.

Table (7): Cronbach's Alpha Coefficient for the Questionnaire Axes reliability (n=30)

\begin{tabular}{c|c}
\hline \multicolumn{2}{c}{ Cronbach's Alpha } \\
\hline \multicolumn{2}{c}{ 0.87 } \\
\hline Axis & Alpha Coefficient for Item and Axis \\
\hline 1 & 0.82 \\
\hline 2 & 0.79 \\
\hline 3 & 0.81 \\
\hline 4 & 0.85 \\
\hline 5 & 0.78 \\
\hline 6 & 0.83 \\
\hline 7 & 0.84 \\
\hline 8 & 0.86 \\
\hline 9 & 0.80 \\
\hline
\end{tabular}

Table (7) shows Cronbach's Alpha coefficients for axes reliability.

Table (8): Total Cronbach's Alpha Coefficient for the Questionnaire (n=30)

The Questionnaire

Creative Marketing as an Approach for Gaining Competitive Advantage in Sports Clubs

\section{Correlation Coefficient}

0.86

Table (8) shows that Cronbach's Alpha coefficient of the questionnaire (0.86).

\section{Main Application:}

The researcher applied the questionnaire to the main sample $(n=150)$ from 1-9-2014 to 15-10-2014. The questionnaire was corrected according to a three-point likert scale (agree $=3$ - somehow $=2-$ disagree $=1$ ).

Statistical Treatment:

The researcher used SPSS software to calculate: correlation coefficient - Cronbach's Alpha - relative weight - relative importance $-\mathrm{CHI}^{2}$ 
Results \& Discussion:

Table (9): Participants' Opinions on the First Axis (n=150)

\begin{tabular}{|c|c|c|c|c|c|c|c|c|c|}
\hline \multirow{2}{*}{ Item } & \multicolumn{2}{|c|}{ Agree } & \multicolumn{2}{|c|}{ Somehow } & \multicolumn{2}{|c|}{ Disagree } & \multirow{2}{*}{$\begin{array}{l}\text { Relative } \\
\text { weight }\end{array}$} & \multirow{2}{*}{$\begin{array}{c}\text { Relative } \\
\text { Importance }\end{array}$} & \multirow{2}{*}{$\mathrm{CHI}^{2}$} \\
\hline & F & $\%$ & $\mathrm{~F}$ & $\%$ & $\mathrm{~F}$ & $\%$ & & & \\
\hline 1 & 63 & 42 & 17 & 11.33 & 70 & 46.67 & 293 & 65.11 & 33.16 \\
\hline 2 & 67 & 44.67 & 10 & 6.67 & 73 & 48.67 & 294 & 65.33 & 48.36 \\
\hline 3 & 54 & 36 & 36 & 24 & 60 & 40 & 294 & 65.33 & 6.24 \\
\hline 4 & 86 & 57.33 & 20 & 13.33 & 44 & 29.33 & 342 & 76 & 44.64 \\
\hline 5 & 40 & 26.67 & 15 & 10 & 95 & 63.33 & 245 & 54.44 & 67 \\
\hline 6 & 23 & 15.33 & 30 & 20 & 97 & 64.67 & 226 & 50.22 & 66.76 \\
\hline 7 & 108 & 72 & 12 & 8 & 30 & 20 & 378 & 84 & 104.16 \\
\hline 8 & 40 & 26.67 & 23 & 15.33 & 87 & 58 & 253 & 56.22 & 43.96 \\
\hline 9 & 22 & 14.67 & 20 & 13.33 & 108 & 72 & 214 & 47.56 & 100.96 \\
\hline 10 & 68 & 45.33 & 9 & 6 & 73 & 48.67 & 295 & 65.56 & 50.68 \\
\hline 11 & 38 & 25.33 & 5 & 3.33 & 107 & 71.33 & 231 & 51.33 & 108.36 \\
\hline
\end{tabular}

Table (9) showed frequency, percentage, relative weight, relative importance and $\mathrm{CHI}^{2}$ of participants' opinions on the first axis. It is clear that $\mathrm{CHI}^{2}$ table value (5.99) is less than its calculated values ranging from (6.24) to 108.36). Relative importance ranged from $(47.56 \%)$ to $(84 \%)$ and this reflects the fact that participants are highly aware of the concept of creative marketing. This also indicates that clubs seek new marketing ideas and make these ideas applicable through marketing practices and seeking new markets away off competitors. Also, clubs target new beneficiaries who were not originally potential clients. Furthermore, clubs try to invent new needs for their members and introduce new products that did not exist before with special concentration on partial innovation like making relatively slight improvements on the clubs commodities or services and facing external threats with innovative methods. The club should also use creative marketing as a permanent strategy.

This is in agreement with Abd El-Aty, K. (2000), Gebreel, M. (2001), Al-Hagga, H. (2001), Al-Mogy, K. (2002), Atia, M. (2005), Al-Banna, D. (2005), Al-GaMAL, n. (2007), Abu Al-Naga, A. (2008), Ghanbari, \& Saboonchi (2013), Jeoung Harley (41), Green, A. (36) and Schiele, H. (2006). (2) (24) (11) (14) (16) (9) (10) (5) (25) (33) (27) (48).

These studies indicated a strong proportionate relation between the concept of innovation adopted by organizations in its activities and its competitive position. Organizations using modern technology and e-administration enjoy competitive advantages over the whole market. Clubs should seek new marketing ideas and apply them in their marketing activities.

To apply creative marketing, companies should seek continuous improvements of their products to achieve new benefits for customers and satisfy their needs and desires. In addition, creative marketing requires new and modern marketing processes away off traditional concepts and practices (48: 35) (27: 73).

This clearly indicates that participants understand the concept of creative marketing. There is a general trend among sports clubs to use creative marketing urgently. This can be done through concentration on the product (commodity or service), price, promotion, distribution or all of them at once. In other words, this type of creativity leads to all the components of the marketing blend $\left(4 \mathrm{P}_{\mathrm{S}}\right)$. 
$-8-$

Accordingly, creative marketing is not limited to generating or finding new ideas. Instead, it includes practical application of these ideas. To be successful, it should use all new ideas for the benefit of the organization. It is not limited to a specific marketing field but it includes all fields. There are several examples of creative marketing in the world of business that reflect its applicability in various marketing fields.

Table (10): Participants' Opinions on the Second Axis (n=150)

\begin{tabular}{|c|c|c|c|c|c|c|c|c|c|}
\hline \multirow{2}{*}{ Item } & \multicolumn{2}{|c|}{ Agree } & \multicolumn{2}{|c|}{ Somehow } & \multicolumn{2}{|c|}{ Disagree } & \multirow{2}{*}{$\begin{array}{l}\text { Relative } \\
\text { weight }\end{array}$} & \multirow{2}{*}{$\begin{array}{c}\text { Relative } \\
\text { Importance }\end{array}$} & \multirow{2}{*}{$\mathrm{CHI}^{2}$} \\
\hline & $\mathrm{F}$ & $\%$ & $\mathrm{~F}$ & $\%$ & $\mathrm{~F}$ & $\%$ & & & \\
\hline 1 & 17 & 11.33 & 10 & 6.67 & 123 & 82 & 194 & 43.11 & 160.36 \\
\hline 2 & 75 & 50 & 10 & 6.67 & 65 & 43.33 & 310 & 68.89 & 49 \\
\hline 3 & 54 & 36 & 33 & 22 & 63 & 42 & 291 & 64.67 & 9.48 \\
\hline 4 & 20 & 13.33 & 21 & 14 & 109 & 72.67 & 211 & 46.89 & 104.44 \\
\hline 5 & 64 & 42.67 & 19 & 12.67 & 67 & 44.67 & 297 & 66 & 28.92 \\
\hline 6 & 85 & 56.67 & 25 & 16.67 & 40 & 26.67 & 345 & 76.67 & 39 \\
\hline 7 & 59 & 39.33 & 21 & 14 & 70 & 46.67 & 289 & 64.22 & 26.44 \\
\hline 8 & 37 & 24.67 & 80 & 53.33 & 33 & 22 & 304 & 67.56 & 27.16 \\
\hline 9 & 33 & 22 & 87 & 58 & 30 & 20 & 303 & 67.33 & 41.16 \\
\hline 10 & 40 & 26.67 & 75 & 50 & 35 & 23.33 & 305 & 67.78 & 19 \\
\hline 11 & 95 & 63.33 & 15 & 10 & 40 & 26.67 & 355 & 78.89 & 67 \\
\hline 12 & 87 & 58 & 40 & 26.67 & 23 & 15.33 & 364 & 80.89 & 43.96 \\
\hline 13 & 65 & 43.33 & 35 & 23.33 & 50 & 33.33 & 315 & 70 & 9 \\
\hline
\end{tabular}

CHI $^{2}$ table value on $P \leq 0.05=5.99$

Table (10) showed frequency, percentage, relative weight, relative importance and $\mathrm{CHI}^{2}$ of participants' opinions on the second axis. It is clear that $\mathrm{CHI}^{2}$ table value (5.99) is less than its calculated values ranging from (9) to (160.36). Relative importance ranged from (43.11\%) to (80.89\%) and this reflects the fact that participants are fully aware of the importance of signing contracts with international clubs and companies as a means of creativity. Clubs work on cooperation agreements with international clubs to get new and modern things in the sports world. These agreements are the source of creativity.

These agreements are used in introducing creative marketing ideas. Financial cost of these agreements are considered fair price to get such inventions. Clubs should depend on their own capabilities to get the latest trends in marketing. These agreements should be used to generate new financial resources. In addition, clubs should think about opening academies in some Arab countries and resolving challenges (social - economic - political) that face the club in the society. This means to create new demands on the club's products (commodities services) nationally and internationally. Furthermore, clubs should work on resolving marketing issues that may face them to increase their fund and establish good reputation on the local and Arab levels. This increases the club's competitive advantage on these levels.

This is consistent with Al-Mogy, K. (2002), Rady, B. (2002), Salem, a. (2004), alSayed, S. (2004), Abu Al-Naga, A. (2008), Gomaa, S. (2004), Zoromba, M. (2007), Rady et al (2010), Derbala, A. (2012), Afifi, a. (2013) and Iheanacho \& Rufus (2013) who indicated that contract agreements among clubs and international companies represent a very important source of creativity. It is very important to use scientific principles of sports administration and to consider sports economics through finding new resources for funding sports activities. In addition, non-traditional ways of thinking should be utilized in funding and financing sports activities. Therefore, gradual privatization of sports clubs should be considered (25) (44) (46) (13) (5) (26) (53) (43) (8) (31). 
This indicates a general trend among sports clubs to accept the strategy of contracting with international clubs and companies as a source of creativity. This contributes in establishing a creative marketing policy that enables clubs to overcome the severe limitations in research due to the lack of financial resources and weak relations among clubs and universities.

Table (11): Participants' Opinions on the Third Axis $(n=150)$

\begin{tabular}{|c|c|c|c|c|c|c|c|c|c|}
\hline \multirow{2}{*}{ Item } & \multicolumn{2}{|c|}{ Agree } & \multicolumn{2}{|c|}{ Somehow } & \multicolumn{2}{|c|}{ Disagree } & \multirow{2}{*}{$\begin{array}{l}\text { Relative } \\
\text { weight }\end{array}$} & \multirow{2}{*}{$\begin{array}{c}\text { Relative } \\
\text { Importance }\end{array}$} & \multirow{2}{*}{$\mathrm{CHI}^{2}$} \\
\hline & $\mathrm{F}$ & $\%$ & $\mathrm{~F}$ & $\%$ & $\mathrm{~F}$ & $\%$ & & & \\
\hline 1 & 55 & 36.67 & 35 & 23.33 & 60 & 40 & 295 & 65.56 & 7 \\
\hline 2 & 44 & 29.33 & 20 & 13.33 & 86 & 57.33 & 258 & 57.33 & 44.64 \\
\hline 3 & 45 & 30 & 70 & 46.67 & 35 & 23.33 & 310 & 68.89 & 13 \\
\hline 4 & 30 & 20 & 12 & 8 & 108 & 72 & 222 & 49.33 & 104.16 \\
\hline 5 & 60 & 40 & 15 & 10 & 75 & 50 & 285 & 63.33 & 39 \\
\hline 6 & 27 & 18 & 80 & 53.33 & 43 & 28.67 & 284 & 63.11 & 29.56 \\
\hline 7 & 43 & 28.67 & 25 & 16.67 & 82 & 54.67 & 261 & 58 & 33.96 \\
\hline 8 & 67 & 44.67 & 33 & 22 & 50 & 33.33 & 317 & 70.44 & 11.56 \\
\hline 9 & 42 & 28 & 64 & 42.67 & 44 & 29.33 & 298 & 66.22 & 6.92 \\
\hline 10 & 40 & 26.67 & 32 & 21.33 & 78 & 52 & 262 & 58.22 & 24.16 \\
\hline 11 & 76 & 50.67 & 44 & 29.33 & 30 & 20 & 346 & 76.89 & 22.24 \\
\hline 12 & 45 & 30 & 32 & 21.33 & 73 & 48.67 & 272 & 60.44 & 17.56 \\
\hline 13 & 40 & 26.67 & 23 & 15.33 & 87 & 58 & 253 & 56.22 & 43.96 \\
\hline 14 & 62 & 41.33 & 27 & 18 & 61 & 40.67 & 301 & 66.89 & 15.88 \\
\hline 15 & 33 & 22 & 33 & 22 & 84 & 56 & 249 & 55.33 & 34.68 \\
\hline 16 & 25 & 16.67 & 41 & 27.33 & 84 & 56 & 241 & 53.56 & 37.24 \\
\hline 17 & 39 & 26 & 43 & 28.67 & 68 & 45.33 & 271 & 60.22 & 9.88 \\
\hline
\end{tabular}

Table (11) showed frequency, percentage, relative weight, relative importance and $\mathrm{CHI}^{2}$ of participants' opinions on the third axis. It is clear that $\mathrm{CHI}^{2}$ table value (5.99) is less than its calculated values ranging from (6.92) to (104.16). Relative importance ranged from $(49.33 \%)$ to $(76.89 \%)$ and this reflects the fact that participants are convinced with the importance of considering quality standards of the sports product. The product should look attractive to get customers' attention. Production can be expanded with increased demands. Products should be introduced with a suitable price without any extra costs. In addition, the club should compete with other clubs providing the same product and to put its products in various markets. Using creative marketing leads to quick improvements on the current products. The club should consider the attractive qualities of the product to attract more customers. In addition, the club should work on improving current products and providing new one for both current and potential customers through traditional and creative methods of marketing. Furthermore, the club should generate a perspective about the product's life span (commodity - service). Clubs should carefully and continually improve their products and test its products for customer satisfaction. Also, clubs should consider opening new markets through creative marketing.

This is consistent with Al-Hagga, H. (2001), Gebreel, M. (2001), Atia, M. (2005), Rady, B. (2002). Abu Al-Naga, (2008), Zoromba, M. (2007), Afifi, A. (2013), Al-Kahtany, N. (2013) and Mafini \& Dhurup (2014) who indicated that clubs should consider quality standards when developing sports products. These products should be introduced in an attractive shape for customers as attractiveness is very important for new customers. Clubs also should produce new products for current and potential customers (11) (24) (16) (44) (5) (53) (8) (12) (38).

This indicates the importance of creative product for acquiring competitive advantage for sports clubs. 
Table (12): Participants' Opinions on the Fourth Axis $(\mathbf{n}=150)$

\begin{tabular}{|c|c|c|c|c|c|c|c|c|c|}
\hline \multirow{2}{*}{ Item } & \multicolumn{2}{|c|}{ Agree } & \multicolumn{2}{|c|}{ Somehow } & \multicolumn{2}{|c|}{ Disagree } & \multirow{2}{*}{$\begin{array}{l}\text { Relative } \\
\text { weight }\end{array}$} & \multirow{2}{*}{$\begin{array}{c}\text { Relative } \\
\text { Importance }\end{array}$} & \multirow{2}{*}{$\mathrm{CHI}^{2}$} \\
\hline & $\mathrm{F}$ & $\%$ & $\mathrm{~F}$ & $\%$ & $\mathrm{~F}$ & $\%$ & & & \\
\hline 1 & 40 & 26.67 & 15 & 10 & 95 & 63.33 & 245 & 54.44 & 67 \\
\hline 2 & 40 & 26.67 & 23 & 15.33 & 87 & 58 & 253 & 56.22 & 43.96 \\
\hline 3 & 85 & 56.67 & 8 & 5.33 & 57 & 38 & 328 & 72.89 & 60.76 \\
\hline 4 & 61 & 40.67 & 16 & 10.67 & 73 & 48.67 & 288 & 64 & 36.12 \\
\hline 5 & 68 & 45.33 & 9 & 6 & 73 & 48.67 & 295 & 65.56 & 50.68 \\
\hline 6 & 55 & 36.67 & 35 & 23.33 & 60 & 40 & 295 & 65.56 & 7 \\
\hline 7 & 30 & 20 & 12 & 8 & 108 & 72 & 222 & 49.33 & 104.16 \\
\hline 8 & 23 & 15.33 & 30 & 20 & 97 & 64.67 & 226 & 50.22 & 66.76 \\
\hline 9 & 35 & 23.33 & 10 & 6.67 & 105 & 70 & 230 & 51.11 & 97 \\
\hline 10 & 44 & 29.33 & 20 & 13.33 & 86 & 57.33 & 258 & 57.33 & 44.64 \\
\hline 11 & 100 & 66.67 & 20 & 13.33 & 30 & 20 & 370 & 82.22 & 76 \\
\hline 12 & 50 & 33.33 & 30 & 20 & 70 & 46.67 & 280 & 62.22 & 16 \\
\hline 13 & 30 & 20 & 13 & 8.67 & 107 & 71.33 & 223 & 49.56 & 100.36 \\
\hline 14 & 40 & 26.67 & 18 & 12 & 92 & 61.33 & 248 & 55.11 & 57.76 \\
\hline
\end{tabular}

Table (12) showed frequency, percentage, relative weight, relative importance and $\mathrm{CHI}^{2}$ of participants' opinions on the fourth axis. It is clear that $\mathrm{CHI}^{2}$ table value (5.99) is less than its calculated values ranging from (7) to (104.16). Relative importance ranged from $(49.33 \%)$ to $(82.22 \%)$ and this reflects the fact that participants are aware of the importance of enhancing product delivery skills for club workers during contact. Marketing department of the club should perform periodical research works on providing sports services. Clubs should directly deliver their products and concentrate on its qualities and attractiveness. Clubs should use modern technology in marketing and delivering products and this leads to decreasing the timeframe of delivery. Also, clubs should use new windows for delivery in addition to emarketing of products. Furthermore, clubs should distribute their products in various markets (universities - schools - hotels) in addition to exporting products holding the club's trademark.

This is consistent with Huber (2002), Lichtenauer (2005), Zoromba, M. (2007), Ioakimidis (2010), Rady et al (2010), Chanbari \& Saboonchi (2013), Radikonyana (2013), Ekmekci (2013), Radzuwan et al (2013), Dlodlo \& Dhurup (2013), Kuzma et al (2014) and Mafini \& Dhurup (2014) who indicated the importance of marketing via modern technology like the internet and social networks. (36) (32) (25) (42) (22) (45) (21) (35) (38).

The internet is now spreading all over Egypt. Previous studies indicated that modern technology should be used to improve creative marking in sport.

Technology has a significant effect on the way sports marketers develop their strategies to reach for target groups. Satellite technology and global TV networks enabled sports marketers of sports with high viewing rates to reach for the global market through their enhanced sound tracks and video clips. Technological aids in the sports field are numerous. The internet appeared by the end of the last century and most sports fans think it is a creative tool for communication with their favorite sports (23: 413). 
Harvard (1998) indicated that companies and organizations can gain competitive advantage from a very important source; that is gathering information as it increases their awareness of their intellectual property. The internet is a dynamic tool that created several ways to enable sports organizations to improve their organizational level through categorizing, gathering and storing information electronically. Types of information include athletes and commercial activities of fans and supporters. These processes are ever growing. Therefore, most organizations exist strongly on the internet through specially designed websites for various purposes. These websites are platforms for spreading the organizations' messages. In addition, it can be used to develop public relations with the target audience (29: 111).

Clubs invest their resources in modern technology to gain a bigger market share and to grow more quickly and sustain more revenues compared to their competitors. This has positive effects on service quality provided for the target groups. Therefore, clubs are free in taking the slow path in using modern technology but they should know that they will be far behind their competitors when talking about revenues and quality products to compete with in the market.

Table (13): Participants' Opinions on the Fifth Axis (n=150)

\begin{tabular}{|c|c|c|c|c|c|c|c|c|c|}
\hline \multirow{2}{*}{ Item } & \multicolumn{2}{|c|}{ Agree } & \multicolumn{2}{|c|}{ Somehow } & \multicolumn{2}{|c|}{ Disagree } & \multirow{2}{*}{$\begin{array}{l}\text { Relative } \\
\text { weight }\end{array}$} & \multirow{2}{*}{$\begin{array}{l}\text { Relative } \\
\text { Importance }\end{array}$} & \multirow{2}{*}{$\mathrm{CHI}^{2}$} \\
\hline & $\mathrm{F}$ & $\%$ & $\mathrm{~F}$ & $\%$ & $\mathrm{~F}$ & $\%$ & & & \\
\hline 1 & 70 & 46.67 & 20 & 13.33 & 60 & 40 & 310 & 68.89 & 28 \\
\hline 2 & 28 & 18.67 & 25 & 16.67 & 97 & 64.67 & 231 & 51.33 & 66.36 \\
\hline 3 & 97 & 64.67 & 23 & 15.33 & 30 & 20 & 367 & 81.56 & 66.76 \\
\hline 4 & 62 & 41.33 & 15 & 10 & 73 & 48.67 & 289 & 64.22 & 37.96 \\
\hline 5 & 42 & 28 & 19 & 12.67 & 89 & 59.33 & 253 & 56.22 & 50.92 \\
\hline 6 & 73 & 48.67 & 9 & 6 & 68 & 45.33 & 305 & 67.78 & 50.68 \\
\hline 7 & 43 & 28.67 & 12 & 8 & 95 & 63.33 & 248 & 55.11 & 70.36 \\
\hline 8 & 43 & 28.67 & 20 & 13.33 & 87 & 58 & 256 & 56.89 & 46.36 \\
\hline 9 & 63 & 42 & 17 & 11.33 & 70 & 46.67 & 293 & 65.11 & 33.16 \\
\hline 10 & 62 & 41.33 & 15 & 10 & 73 & 48.67 & 289 & 64.22 & 37.96 \\
\hline 11 & 30 & 20 & 11 & 7.33 & 109 & 72.67 & 221 & 49.11 & 108.04 \\
\hline 12 & 31 & 20.67 & 20 & 13.33 & 99 & 66 & 232 & 51.56 & 73.24 \\
\hline
\end{tabular}

Table (13) showed frequency, percentage, relative weight, relative importance and $\mathrm{CHI}^{2}$ of participants' opinions on the fifth axis. It is clear that $\mathrm{CHI}^{2}$ table value (5.99) is less than its calculated values ranging from (28) to (108.4). Relative importance ranged from $(51.33 \%)$ to $(81.56 \%)$ and this reflects the fact that participants know well the importance of using non-traditional promotion methods depending on the promotion ideas of the marketing department instead of using external ideas. Clubs should depend on the internet (e-marketing), develop marketing personnel's capabilities in advertising and use text messages to promote commodities and services. Also, clubs should use all events (athletic - artistic - cultural social) in promoting their services. Advertisements should be new and creative. Clubs also should consider opening franchise and academies all around the country to reach as many clients as they can.

This is consistent with Abu Al-Naga (2008), Ekmekci (2013), Radzuwan et al (2013), Dlodlo \& Dhurup (2013), Kuzma et al (2014) and Mafini \& Dhurup (2014) who indicated the importance of marketing via modern technology like the internet and social networks. This identifies a general trend that clubs accept that creative promotion can provide clubs with very effective marketing strategies (5) (22) (45) (21) (35) (38). 
-12 -

It is very important to depend on the club's own ideas. The absence of a specific unit for promotion does not mean that creativity cannot be achieved. Instead, there is a great difference between a permanent organizational unit and managing it via other forms. For example, a temporary committee can be formed for managing creative marketing. Or even, a specific department can handle this task. Further, a specific person can be appointed for this job (7: 10).

The researcher thinks that each sports club should identify how to handle this process according to several factors including the importance, fields, cost and frequency of creative marketing. The most effective factor in promotions is introducing creative ads and this explains the millions of dollars spent on advertisement.

Table (14): Participants' Opinions on the Sixth Axis $(n=150)$

\begin{tabular}{|c|c|c|c|c|c|c|c|c|c|}
\hline \multirow{2}{*}{ Item } & \multicolumn{2}{|c|}{ Agree } & \multicolumn{2}{|c|}{ Somehow } & \multicolumn{2}{|c|}{ Disagree } & \multirow{2}{*}{$\begin{array}{l}\text { Relative } \\
\text { weight }\end{array}$} & \multirow{2}{*}{$\begin{array}{c}\text { Relative } \\
\text { Importance }\end{array}$} & \multirow{2}{*}{$\mathrm{CHI}^{2}$} \\
\hline & $\mathrm{F}$ & $\%$ & $\mathrm{~F}$ & $\%$ & $\mathrm{~F}$ & $\%$ & & & \\
\hline 1 & 32 & 21.33 & 40 & 26.67 & 78 & 52 & 254 & 56.44 & 24.16 \\
\hline 2 & 36 & 24 & 30 & 20 & 84 & 56 & 252 & 56 & 35.04 \\
\hline 3 & 35 & 23.33 & 70 & 46.67 & 45 & 30 & 290 & 64.44 & 13 \\
\hline 4 & 44 & 29.33 & 64 & 42.67 & 42 & 28 & 302 & 67.11 & 6.92 \\
\hline 5 & 35 & 23.33 & 70 & 46.67 & 45 & 30 & 290 & 64.44 & 13 \\
\hline 6 & 43 & 28.67 & 80 & 53.33 & 27 & 18 & 316 & 70.22 & 29.56 \\
\hline 7 & 40 & 26.67 & 30 & 20 & 80 & 53.33 & 260 & 57.78 & 28 \\
\hline 8 & 27 & 18 & 80 & 53.33 & 43 & 28.67 & 284 & 63.11 & 29.56 \\
\hline 9 & 42 & 28 & 64 & 42.67 & 44 & 29.33 & 298 & 66.22 & 6.92 \\
\hline 10 & 62 & 41.33 & 61 & 40.67 & 27 & 18 & 335 & 74.44 & 15.88 \\
\hline 11 & 40 & 26.67 & 23 & 15.33 & 87 & 58 & 253 & 56.22 & 43.96 \\
\hline 12 & 27 & 18 & 62 & 41.33 & 61 & 40.67 & 266 & 59.11 & 15.88 \\
\hline 13 & 78 & 52 & 32 & 21.33 & 40 & 26.67 & 338 & 75.11 & 24.16 \\
\hline 14 & 75 & 50 & 15 & 10 & 60 & 40 & 315 & 70 & 39 \\
\hline 15 & 46 & 30.67 & 60 & 40 & 44 & 29.33 & 302 & 67.11 & 6.04 \\
\hline 16 & 39 & 26 & 43 & 28.67 & 68 & 45.33 & 271 & 60.22 & 9.88 \\
\hline 17 & 27 & 18 & 80 & 53.33 & 43 & 28.67 & 284 & 63.11 & 29.56 \\
\hline 18 & 42 & 28 & 73 & 48.67 & 35 & 23.33 & 307 & 68.22 & 16.36 \\
\hline
\end{tabular}

Table (14) showed frequency, percentage, relative weight, relative importance and $\mathrm{CHI}^{2}$ of participants' opinions on the sixth axis. It is clear that $\mathrm{CHI}^{2}$ table value (5.99) is less than its calculated values ranging from (6.04) to (43.96). Relative importance ranged from $(56 \%)$ to $(75.11 \%)$ and this reflects the fact that participants are fully aware that the current policy of pricing for sports products contribute greatly in convincing customers with such products. Pricing policies in each club depend on specific bases as the product's price should be suitable for the customer. Suitable prices lead products to continue in the market. Therefore, clubs should have flexible policies for pricing to face sever shifts in demand so that when the price increases, the increase should be justified. Prices should be competitive with creative means of discount for members in addition to adopting new ideas for decreasing cost. It is also important to rethink prices every once and a while according to innovation and renewal of products.

This is consistent with Abu Gomaa, N. (2000), Gebreel, M. (2001), Abdin, D. (2005), Ogden (2005), Young et al (2006) Abu Al-Naga, A. (2008) and Kolter \& Debes (2003) who indicated that pricing is a vital component of the marketing blend. It is very important to seek creative methods of pricing like group prices. Prices should be flexible as sales increase with decreased prices and vice versa. Value and price should be balanced as when the price is far 
-13 -

higher than the customer's expected value, the customer will not buy. (6) (24) (4) (40) (52) (5) (34).

Clubs should provide products with suitable prices to reach for all categories of customers inside and outside the club. This increases the product's spread and competitiveness.

Table (15): Participants' Opinions on the Seventh Axis (n=150)

\begin{tabular}{|c|c|c|c|c|c|c|c|c|c|}
\hline \multirow{2}{*}{ Item } & \multicolumn{2}{|c|}{ Agree } & \multicolumn{2}{|c|}{ Somehow } & \multicolumn{2}{|c|}{ Disagree } & \multirow{2}{*}{$\begin{array}{l}\text { Relative } \\
\text { weight }\end{array}$} & \multirow{2}{*}{$\begin{array}{c}\text { Relative } \\
\text { Importance }\end{array}$} & \multirow{2}{*}{$\mathrm{CHI}^{2}$} \\
\hline & $\mathrm{F}$ & $\%$ & $\mathrm{~F}$ & $\%$ & $\mathrm{~F}$ & $\%$ & & & \\
\hline 1 & 40 & 26.67 & 15 & 10 & 95 & 63.33 & 245 & 54.44 & 67 \\
\hline 2 & 10 & 6.67 & 35 & 23.33 & 105 & 70 & 205 & 45.56 & 97 \\
\hline 3 & 30 & 20 & 70 & 46.67 & 50 & 33.33 & 280 & 62.22 & 16 \\
\hline 4 & 23 & 15.33 & 40 & 26.67 & 87 & 58 & 236 & 52.44 & 43.96 \\
\hline 5 & 25 & 16.67 & 22 & 14.67 & 103 & 68.67 & 222 & 49.33 & 84.36 \\
\hline 6 & 35 & 23.33 & 60 & 40 & 55 & 36.67 & 280 & 62.22 & 7 \\
\hline 7 & 62 & 41.33 & 73 & 48.67 & 15 & 10 & 347 & 77.11 & 37.96 \\
\hline 8 & 55 & 36.67 & 60 & 40 & 35 & 23.33 & 320 & 71.11 & 7 \\
\hline 9 & 30 & 20 & 23 & 15.33 & 97 & 64.67 & 233 & 51.78 & 66.76 \\
\hline 10 & 35 & 23.33 & 55 & 36.67 & 60 & 40 & 275 & 61.11 & 7 \\
\hline 11 & 18 & 12 & 40 & 26.67 & 92 & 61.33 & 226 & 50.22 & 57.76 \\
\hline 12 & 35 & 23.33 & 72 & 48 & 43 & 28.67 & 292 & 64.89 & 15.16 \\
\hline
\end{tabular}

Table (15) showed frequency, percentage, relative weight, relative importance and $\mathrm{CHI}^{2}$ of participants' opinions on the seventh axis. It is clear that $\mathrm{CHI}^{2}$ table value (5.99) is less than its calculated values ranging from (7) to (97). Relative importance ranged from $(45.56 \%)$ to $(77.11 \%)$ and this reflects the fact that participants are aware of the importance of monitoring service development in other Egyptian and international clubs as competitors. It is also important to keep up with press releases concerning specific warnings about risks related to similar services. Every club should have a data bank and members and works should have the freedom to apply their ideas freely to the administration. In addition, marketing department should communicate effectively with other departments with special consideration directed to communication with external research centers to gain more creative ideas and research results applicable in the sports field. The club should send representatives to attend conferences and seminars concerning sports marketing and to make use of successful international experiences in this field.

This is consistent with Samy, W. (2000), Selim, A. (2003), Shalaby, S. (2004), Mohamed, N. \& Shalaby, S. (2005), Atia, M. (2005), Abu Al-Naga, A. (2008), Omar, S. (2010), Abbas, M. (2012), Al-Kahtany, N. (2013) and Afifi, A. (2013) who indicated that the importance of providing suitable space in the media for marketing various sports and this indicates the media effect of the club (47) (49) (50) (3) (16) (5) (41) (1) (12) (8).

It is very important to analyze all the information related to promotion capabilities when planning sports projects. The information system of creative marketing is the most effective element among marketing requirements due to the importance of information as its value increases when it is related to new creative marketing ideas. Through creative marketing, the club can decrease the costs and deepen its distinction. This can never be achieved unless the club has a unique distinction. If competitors manage to imitate it or even provide an alternative, the club will find itself again in position for seeking an alternative creative marketing plan. 
-14 -

Table (16): Participants' Opinions on the Eighth Axis $(\mathbf{n}=150)$

\begin{tabular}{|c|c|c|c|c|c|c|c|c|c|}
\hline \multirow{2}{*}{ Item } & \multicolumn{2}{|c|}{ Agree } & \multicolumn{2}{|c|}{ Somehow } & \multicolumn{2}{|c|}{ Disagree } & \multirow{2}{*}{$\begin{array}{l}\text { Relative } \\
\text { weight }\end{array}$} & \multirow{2}{*}{$\begin{array}{c}\text { Relative } \\
\text { Importance }\end{array}$} & \multirow{2}{*}{$\mathrm{CHI}^{2}$} \\
\hline & $\mathrm{F}$ & $\%$ & $\mathrm{~F}$ & $\%$ & $\mathrm{~F}$ & $\%$ & & & \\
\hline 1 & 47 & 31.33 & 85 & 56.67 & 18 & 12 & 329 & 73.11 & 45.16 \\
\hline 2 & 35 & 23.33 & 60 & 40 & 55 & 36.67 & 280 & 62.22 & 7 \\
\hline 3 & 30 & 20 & 13 & 8.67 & 107 & 71.33 & 223 & 49.56 & 100.36 \\
\hline 4 & 20 & 13.33 & 44 & 29.33 & 86 & 57.33 & 234 & 52 & 44.64 \\
\hline 5 & 32 & 21.33 & 16 & 10.67 & 102 & 68 & 230 & 51.11 & 83.68 \\
\hline 6 & 55 & 36.67 & 35 & 23.33 & 60 & 40 & 295 & 65.56 & 7 \\
\hline 7 & 48 & 32 & 32 & 21.33 & 70 & 46.67 & 278 & 61.78 & 14.56 \\
\hline 8 & 34 & 22.67 & 13 & 8.67 & 103 & 68.67 & 231 & 51.33 & 88.68 \\
\hline 9 & 33 & 22 & 30 & 20 & 87 & 58 & 246 & 54.67 & 41.16 \\
\hline 10 & 26 & 17.33 & 0 & 0 & 124 & 82.67 & 202 & 44.89 & 171.04 \\
\hline 11 & 16 & 10.67 & 0 & 0 & 134 & 89.33 & 182 & 40.44 & 214.24 \\
\hline 12 & 19 & 12.67 & 0 & 0 & 131 & 87.33 & 188 & 41.78 & 200.44 \\
\hline 13 & 17 & 11.33 & 0 & 0 & 133 & 88.67 & 184 & 40.89 & 209.56 \\
\hline 14 & 24 & 16 & 0 & 0 & 126 & 84 & 198 & 44 & 179.04 \\
\hline 15 & 48 & 32 & 0 & 0 & 102 & 68 & 246 & 54.67 & 104.16 \\
\hline
\end{tabular}

Table (16) showed frequency, percentage, relative weight, relative importance and $\mathrm{CHI}^{2}$ of participants' opinions on the eighth axis. It is clear that $\mathrm{CHI}^{2}$ table value (5.99) is less than its calculated values ranging from (7) to (214.24). Relative importance ranged from $(40.44 \%)$ to $(73.11 \%)$ and this reflects the fact that participants are aware that the higher level of administration should be interested in new creative marketing ideas. The higher administration should be committed to supporting creative marketing and including it into the permanent strategy of the club. All other administrative levels should be encouraged to apply and discuss new marketing ideas so that creativity and innovation become the working spirit of the club. The higher administration should also award persons with creative ideas and creativity and innovation should be included among the criteria of evaluating workers. In addition, persons should be professionally developed through continuous training on new expertise in the field of sports marketing. Creative marketing should be handled by an integrated team.

This is consistent with Samy, W. (2000), Gebreel, M. (2001), Al-Mogy, K. (2002), Selim, A. (2003), Salem, A. (2004), Atia, M. (2005), Mohamed, N. \& Shalaby, S. (2005), Abu Al-Naga, A. (2008), Zoromba, M. (2007) and Abbas, M. (2012) who indicated that marketing personnel re very important for sports marketing and those should be qualified in specialized faculties and institutes as those individuals specialized in sports marketing are very rare. Furthermore, clubs should establish a professional marketing department and provide training courses for marketing personnel on how to generate creative ideas (47) (24) (25) (49) (46) (16) (3) (5) (53) (1).

Nowadays, real competition in centered around innovation and creativity in all fields as innovation is the highest value add in commodity and service marketing. Continuous improvements in all field of marking provides clubs with the best competitive form. This provides the club with a strategic advantage that supports its competitive position through which resources can increase. The only path for a sports club to flourish is through creative marketing. 
-15 -

Table (17): Participants' Opinions on the Ninth Axis (n=150)

\begin{tabular}{|c|c|c|c|c|c|c|c|c|c|}
\hline \multirow{2}{*}{ Item } & \multicolumn{2}{|c|}{ Agree } & \multicolumn{2}{|c|}{ Somehow } & \multicolumn{2}{|c|}{ Disagree } & \multirow{2}{*}{$\begin{array}{l}\text { Relative } \\
\text { weight }\end{array}$} & \multirow{2}{*}{$\begin{array}{c}\text { Relative } \\
\text { Importance }\end{array}$} & \multirow{2}{*}{$\mathrm{CHI}^{2}$} \\
\hline & $\mathrm{F}$ & $\%$ & $\mathrm{~F}$ & $\%$ & $\mathrm{~F}$ & $\%$ & & & \\
\hline 1 & 43 & 28.67 & 80 & 53.33 & 27 & 18 & 316 & 70.22 & 29.56 \\
\hline 2 & 60 & 40 & 63 & 42 & 27 & 18 & 333 & 74 & 15.96 \\
\hline 3 & 52 & 34.67 & 76 & 50.67 & 22 & 14.67 & 330 & 73.33 & 29.28 \\
\hline 4 & 32 & 21.33 & 40 & 26.67 & 78 & 52 & 254 & 56.44 & 24.16 \\
\hline 5 & 76 & 50.67 & 33 & 22 & 41 & 27.33 & 335 & 74.44 & 20.92 \\
\hline 6 & 44 & 29.33 & 64 & 42.67 & 42 & 28 & 302 & 67.11 & 6.92 \\
\hline 7 & 80 & 53.33 & 43 & 28.67 & 27 & 18 & 353 & 78.44 & 29.56 \\
\hline 8 & 61 & 40.67 & 62 & 41.33 & 27 & 18 & 334 & 74.22 & 15.88 \\
\hline 9 & 39 & 26 & 43 & 28.67 & 68 & 45.33 & 271 & 60.22 & 9.88 \\
\hline 10 & 41 & 27.33 & 80 & 53.33 & 29 & 19.33 & 312 & 69.33 & 28.44 \\
\hline 11 & 84 & 56 & 33 & 22 & 33 & 22 & 351 & 78 & 34.68 \\
\hline 12 & 84 & 56 & 41 & 27.33 & 25 & 16.67 & 359 & 79.78 & 37.24 \\
\hline 13 & 43 & 28.67 & 84 & 56 & 23 & 15.33 & 320 & 71.11 & 38.68 \\
\hline 14 & 44 & 29.33 & 74 & 49.33 & 32 & 21.33 & 312 & 69.33 & 18.72 \\
\hline 15 & 48 & 32 & 60 & 40 & 42 & 28 & 306 & 68 & 3.36 \\
\hline 16 & 41 & 27.33 & 79 & 52.67 & 30 & 20 & 311 & 69.11 & 26.44 \\
\hline
\end{tabular}

Table (17) showed frequency, percentage, relative weight, relative importance and $\mathrm{CHI}^{2}$ of participants' opinions on the ninth axis. It is clear that $\mathrm{CHI}^{2}$ table value (5.99) is less than its calculated values ranging from (6.92) to (38.68). Relative importance ranged from $(56.44 \%)$ to $(79.78 \%)$ and this reflects the fact that participants are aware that competitive advantage means the club's ability to outperform its competitors in providing services that distinguish it from them and this leads to increasing its resources. To gain the competitive advantage, the club may follow the advantage of decreased cost in addition to providing unique services that may lead to discovering new services more effective than those provided by competitors. This uniqueness enables the club to win the competition and through strategic thinking this may become the permanent, continuous and renewable competitive advantage according to the requirements of external environment and the club's financial resources. Competitive advantage should be in balance with results and objectives desired by the club on the shot and long run. Knowles is the most important factor in creating competitive advantage through creativity.

This is consistent with Abu Gomaa, N. (2000), Haddad, S. \& Al-Ghadeer, H. (2004), Van Geerde \& Mela (2004), Anonymous (2005), Maddever (2005), Schiele, H. (2006) and Abu Al-Naga, A. (2008) who indicated that competition through innovation and creativity enables the organization to escape the trap of price competition. Innovation enables organizations to create new products and alternatives that make the organization outperform its competitors as a service provider and to fulfill the ever changing requirements and desires of the customers. They also indicated a strong positive relationship between creative marketing on one hand and the competitive advantage of the organization, its market share, its revenues and its new customers on the other. But this depends on that the organization is more creative than its competitor. Organizations using creative marketing can achieve competitive advantage through unique products, its mental image, its reputation and other factors contributing in the competitive advantage. The competitive advantage has positive effects on the organization like maintaining, or even increasing, its market share, increasing sales and profits and the potentiality of reaching a leading market position (with all its benefits). Furthermore, it leads to gaining new customers and maintaining the current ones. Through creative marketing, a competitive advantage can be found and if it is maintained 


$$
-16-
$$

longer, its benefits can be harvested. It is maintaining the competitive advantage, not merely finding it, that matters. (6) (28) (51) (15) (37) (48) (5).

\section{Conclusions:}

According to these results, the researcher concluded the following:

- Sports clubs use creative marketing as a permanent strategy

- Sports clubs create new markets

- Sports clubs are interested in contracting with international clubs and companies as a source of creativity

- Sports clubs open academies in some Arab countries

- Sports clubs consider quality standards of sports products

- Sports clubs have a clear perspective about the life span of the product (commodity service)

- Sports clubs improve the product delivery skills of marketing personnel

- Sports clubs perform research studies through their marketing departments

- Sports clubs use modern technology in product delivery

- Sports clubs are welling o export their products bearing their trade mark

- Sports clubs depend on promotion ideas of the marketing department instead of ideas of external parties

- Sports clubs use e-promotion

- Sports clubs establish new franchise

- Sports clubs use flexible pricing policy

- Sports clubs depends on discounts on stagnant commodity

- Sports clubs monitor services provided by other competitors (Egyptian or international clubs)

- Sports clubs adopt their members' creative ideas

- Sports clubs follow media warning policies for counterfeit goods

- Sports clubs establish data banks

- Sports clubs contact research institutes to get creative ideas

- Sports clubs use successful international experiences in creative marketing

- Higher administration are interested in discussing new creative marketing ideas

- Higher administration supports creative marketing

- Various administrative levels should apply and discuss new marketing ideas

- The organizational structure of the creative marketing in the club should be as an integrated team

- Sports clubs are aware of the importance of competitive advantage

- Sports clubs plan for marketing o the short and long run

\section{Recommendations:}

According to these conclusions, the researcher recommends the following:

- Creativity should be considered as one of the administrative tasks like planning, organization, direction and monitoring 
- Creative marketing is not an alternative for traditional marketing. instead they are integrated

- Continuous improvement should be a major objective for sports clubs

- The main resource of creativity should be the customer as a final beneficiary of the product

- We should consider the results of marketing in general and sports marketing in specific

- Training courses, seminars, discussion forums and brain storming meeting should be held for employees of the sports clubs to training them on generating new ideas

- Competition through imitation should stop as its benefits are shirt term and very limited

- Clubs should the policy of establishing new franchise in unused spaces and areas

- Modern methods of communication should be used to contact beneficiaries like eregistry and e-buying

- Higher administration should support creative marketing

- An information system should be used to generate creative ideas concerning all aspects of the sports club

\section{References:}

1- Abbas, Mohamed A. (2008): An Analytical study of investment in Egyptian sports clubs. Master thesis, Faculty of Physical Education for Men - Helwan University Egypt (in Arabic)

2- Abd El-Aty, Khaled I. (2000): Recommended methods for arketing sports championships in Egypt. Master thesis, Faculty of Physical Education for Men Helwan University - Egypt (in Arabic)

3- Abd El-Motteleb, N. \& Shalaby S. (2005): Marketing sports care at the economic associations in Egypt. Scientific Journal - Faculty of Physical Education - Mansoura University - Egypt (in Arabic)

4- Abdin, Doaa M. (2005): A service marketing strategy for the Egyptian Federation of Archery. Master thesis, Faculty of Physical Education for Women - Alexandria University - Egypt (in Arabic)

5- Abu Al-Naga, Amena, (2008): Creative marketing and its effects on the competitive position of Egyptian business associations (applied study on food products sector). $\mathrm{PhD}$ thesis, Faculty of Commerce - Tanta University - Egypt (in Arabic)

6- Abu Gomaa, Naeem H. (2000): Requirements of creative marketing in business associations. Conference of innovation and creativity in Arab administration in the face of $21^{\text {st }}$ century challenges. Arab Organization for Administrative Development - Cairo Egypt (in Arabic).

7- Abu Gomaa, Naeem H. (2003): Creative Marketing. Arab Organization for Administrative Development - Research and Studies - Cairo - Egypt (in Arabic)

8- Afifi, Ahmed M. (2013): The Service marketing role of sports clubs in the $21^{\text {st }}$ century. Master thesis, Faculty of Physical Education- Tanta University - Egypt (in Arabic)

9- Al-Banna, Dalia S. (2005): Measuring perceptions and practices of parties related to sports marketing in some major sports clubs. Master thesis, Faculty of Physical Education for Women - Alexandria University - Egypt (in Arabic)

10- Al-Gamal, Nasr A. (2007): An analytical study for marketing sports facilities of the army forces. PhD thesis, Faculty of Physical Education- Tanta University - Egypt (in Arabic) 


$$
-18-
$$

11- Al-Hagga, Huda H. (2001): Opinions about sports marketing terms in Bahrain. Journal of Faculty of Physical Education for Women - Alexandria university - Egypt (in Arabic)

12- Al-Kahtany, Naief H. (2013): Marketing strategy for sports clubs at KSA. PhD thesis, Faculty of Physical Education for Men - Helwan University - Egypt (in Arabic)

13- Al-Sayed, Sayed M. (2004): Funding sport at the domestic sector: analytical study. PhD thesis, Faculty of Physical Education for Men - Helwan University - Egypt (in Arabic)

14- A-Mogy, Kawthar A. (2002): Marketing and Funding in Sport. Seminar of Economic Administration of Sport - Faculty of Commerce - Cairo University - Egypt (in Arabic)

15- Anonymous (2005)."Fast Second: How Successful Companies by Pass Radical Innovation to Enter and Dominate New Markets." International Journal of Productivity and Performance Management,544(3):300-302

16- Atia, Maher M. (2005): Current status of sports marketing in Egyptian sports clubs. Master thesis, Faculty of Physical Education- Tanta University - Egypt (in Arabic)

17- Atia, Maher M. (2010): Promotion via franchise for local and international marketing of sports commodities and services in the light of globalized sports media. $\mathrm{PhD}$ thesis, Faculty of Physical Education- Tanta University - Egypt (in Arabic)

18- Chourides,P.,Longbottom,D.\&Murphy,W.(2003)."Excellence in Knowledge Management: An Empirical Study to Identify Factors and Performance" . Measuring Business Excellence,7(2) : 29-46

19- Darwish, K. \& Hasanain, M. (2004): Encyclopedia of Sports Administration Continuums at the Dawn of a new Century: Quality and Globalization in Sports Business, Part 1, $1^{\text {st }}$ ED. Dar Al-Fikr Al-Araby - Cairo - Egypt (in Arabic).

20- Derbala, Abd El-Fattah A. (2012): Marketing professional contracts of athletes and its effects on the economics of sports clubs. Master thesis, Faculty of Physical EducationTanta University - Egypt (in Arabic)

21- Dlodlo, N., \& Dhurup, M.: Drivers of E-Marketing Adoption among Small and Medium Enterprises (SMEs) and Variations with Age of Business Owners. Mediterranean Journal of Social Sciences, 4(14), 53,2013

22- Ekmekci, R.: Sport Club Websites Condition: Marketing Oriented Research. International Journal of Business and Management, 8(10), p97 , 2013

23- Fullerton, S: Sports Marketing. New York. (2007)

24- Gebreel, Mohamed R. (2001): Promotion of sports championships and matches using modern concepts of marketing. Master thesis, Faculty of Physical Education for Men Helwan University - Egypt (in Arabic)

25- Ghanbari, M. N., \& Saboonchi,: R. Analysis of role of technology in economic competitiveness of sport in west provinces of Iran. Advances in Applied Science Research, 2013, 4(5):133-137

26- Gomaa, Saud S. (2004): Strategic structure of privatizing sport in UAE. PhD thesis, Faculty of Physical Education for Men - Helwan University - Egypt (in Arabic)

27- Green,A.:Creativity in Puplic Relations, Kogan Page, The Institute of Publication,USA, 2004

28- Haddad, Shafiq \& Al-Ghadeer, Hamad (2004): Innovation and creativity in marketing pharmaceutical products. Faculty of Economy \& Political Sciences - Private University of Applied Sciences - Amman - Jordan (in Arabic)

29- Harvard Business School: Review on Knowledge Management, 1998. :38- Harvard Business School Press. Boston

30- Huber, M. :Sport artikel- Vertrieb uber das Internet. In: Trosien, G.\& Dinkel, M. Sport und neue Markte. Butzbach. ,2002

31- Iheanacho, S. B., \& Rufus, O. :Information and Communication Technology and 
Implication for Sports Management in Nigerian Universities Sports Organizations in the 21st Century. Mediterranean Journal of Social Sciences, 4(5), 113., 2013

32- Ioakimidis, M.:Online marketing of professional sports clubs: engaging fans on a new playing field. International Journal of Sports Marketing and Sponsorship, 11(4), 271282,2010

33- Jeoung Harley :Sport marketing in strategies through the analysis sport consumer behavior and factors in flouncing attainder. Ph.D., University of Minnesota, 2000

34- Kotler,P. \&Debes, F :Lateral Marketing, john Willy\&Sons,Inc,2003

35- Kuzma, Joanne and Bell, Viv and Logue, Ciaran :Marketing in the Football Industry. Journal of Emerging Trends in Computing and Information Sciences, 5 (10). pp. 728 738. ISSN Print: 2079-8407 Online: 2218-6301 , 2014

36- Lichtenauer, P. :Sportsponsoring - Der Verein auf dem Weg in die Professionalitat, www.uni-muenster.de/Sportwissenschaft/Sportku Itu $r$ Weiterbi Id ung Ipdf/rade/sportsponsoring. pdf. ,2005

37- Maddever,M.(2005)."Need A Creative Stimulant? 'Strategy,(Aug):6-17

38- Mafini, C., \& Dhurup, M(2014):Internet marketing benefits among sport organisations in South Africa. African Journal for Physical Health Education, Recreation and Dance, 20(1), 118-132, 2014

39- Masadawy, Yousef (2007): Issue of competitive advantage in the light of globalization challenges, Journal of Humanitarian Sciences - Aleppo - Syria (in Arabic)

40- OGDEN,J. \& OGDEN,D.: Retailing :INTEGRATED:RETIAL MANAGEMENT, HOUGHTON MIFFLIN COMPANY,2005

41- Omar, Sherif A. (2010): Sports marketing plan for sports medicine centers in Egypt. PhD thesis, Faculty of Physical Education- Tanta University - Egypt (in Arabic)

42- Radikonyana, P. S:E-marketing of sports mega-events with specific reference to the 2010 Soccer World Cup (Doctoral dissertation). , 2013

43- Rady, Bahgat Attia, Elshreef, Amany Mohamed Mohsen and Abd-el-Kader, Ahmad Farouk: The Electronic Marketing and Services Quality in Sports Clubs. World Journal of Sport Sciences 3 (S): 804-815 , 2010

44- Rady, Bahgat A. (2002): Total Quality Management as an approach for improving sports administration of Egyptian sports clubs according to current global changes. $\mathrm{PhD}$ thesis, Faculty of Physical Education for Men - Helwan University - Egypt (in Arabic)

45- Radzuwan, R., Hua, K. P., \& Chiu, L. K.: Acceptance of Online Sports Marketing Among Faculty of Sport Science and Recreation Student in UiTM (Perlis). Jurnal Intelek, 8(1), 2013

46- Salem, Ahmed A. (2004): Economic and social effects of privatizing sports clubs. $\mathrm{PhD}$ thesis, Faculty of Physical Education for Men - Helwan University - Egypt (in Arabic)

47- Samy, Waleed A. (2000): Evaluating some methods for marketing sports recreation in some studies and clubs. Master thesis Faculty of Physical Education for Women Helwan university - Egypt (in Arabic)

48- Schiele, $\mathrm{H}$ :"How to Distinguish Innovative Suppliers ? Identifying Innovative Suppliers as New Task for Purchasing" Industrial Marketing Management,35(8):925935

49- Selim, Amany M. (2003): Planning methods for marketing sports championships in Egyptian sports clubs. Master thesis, Faculty of Physical Education- Tanta University Egypt (in Arabic)

50- Shalaby, Saad A. (2004): Management of marketing sponsorship rights in first class Egyptian sports clubs. $8^{\text {th }}$ international conference for physical education and sport Faculty of Physical education for Men - Alexandria University - Egypt (in Arabic)

51- Van Heerde,H.\& Mela,C(2004)"The Dynamic Effect of Innovation on Market 


$$
-20 \text { - }
$$

Structure". Journal of Marketing Research,41(2):166-173

52- Young,R.,Weiss,A.\& Slewart,D.: MARKETING CHAMPIONS:PRACTICAL STRATEGIES FOR IMPROVING MARKETINGS POWER,INFLUENCE AND BUSINESS IMPACT ,WILEY\&SONS,INC,2006

53- Zoromba, Mohamed S. (2007): Evaluation of marketing practices in some sports clubs of Canal Cities in Egypt. Master thesis, Faculty of Physical Education - Port Said Suez Canal University - Egypt (in Arabic) 
Annex (1)

Creative Marketing Questionnaire 


\section{Tanta University \\ Faculty of Physical Education \\ Department of Sports Administration}

Dear

The researcher Ehab Mohamed Khairy (Lecturer - Department of Sports Administration - Faculty of Physical Education - Tanta University) is preparing a study about creative marketing as an approach for gaining the competitive advantage in Major Egyptian sports clubs. Therefore, the researcher prepared a questionnaire as a main tool for gathering data.

The researcher hopes for your cooperation through expressing your opinion about each item of the questionnaire. Please respond to each of the following items according to your opinion. Your responses will have a highly positive effect on the results of this research. All responses are considered confidential and will only be used for scientific purposes.

\section{Best regards}

The researcher

Ehab Mohamed Khairy

Lecturer

Department of Sports Administration

Faculty of Physical Education

Tanta University 
First Axis: Concept of Creative Marketing:

\begin{tabular}{l|l|l|l|l}
\hline No. & \multicolumn{1}{c|}{ Item } & Agree & Somehow & Disagree \\
\hline $1-$ & The club seeks modern marketing ideas & & & \\
\hline $2-$ & $\begin{array}{l}\text { The club is interested in applying modern marketing } \\
\text { ideas in marketing practices }\end{array}$ & & & \\
\hline $3-$ & $\begin{array}{l}\text { The club seeks new markets for its products away off } \\
\text { its competitors }\end{array}$ & $\begin{array}{l}\text { The club targets new customers who are not potential } \\
\text { customers }\end{array}$ & & \\
\hline $4-$ & The club tries to invent new needs for its members & & \\
\hline $6-$ & The club tries to introduce new products & & \\
\hline $7-$ & $\begin{array}{l}\text { The club concentrates on partial innovation (relatively } \\
\text { slight improvements) }\end{array}$ & & \\
\hline $8-$ & The club tries to create new marketing opportunities & & \\
\hline $9-$ & The club face external threats innovatively & & \\
\hline $10-$ & $\begin{array}{l}\text { The club is interested in creativity in marketing } \\
\text { practices in general }\end{array}$ & $\begin{array}{l}\text { The club uses creative marketing as a permanent } \\
\text { strategy }\end{array}$ & & \\
\hline 11 & & \\
\hline
\end{tabular}


Second Axis: Signing Contract Agreements with International Clubs and Companies as a source of Creativity:

\begin{tabular}{|c|c|c|c|c|}
\hline No. & Item & Agree & Somehow & Disagree \\
\hline $1-$ & $\begin{array}{l}\text { The club depends on cooperation agreements with } \\
\text { international clubs to get all that is new in the sports } \\
\text { field }\end{array}$ & & & \\
\hline $2-$ & $\begin{array}{l}\text { These agreements are considered as a source of } \\
\text { Creativity }\end{array}$ & & & \\
\hline $3-$ & $\begin{array}{l}\text { These agreements are used for producing creative } \\
\text { marketing practices }\end{array}$ & & & \\
\hline 4- & Costs of these agreements are considered suitable & & & \\
\hline $5-$ & $\begin{array}{l}\text { The club depends on its own resources to get all that is } \\
\text { new in the marketing field }\end{array}$ & & & \\
\hline $6-$ & $\begin{array}{l}\text { These agreements are used for generating new financial } \\
\text { resources }\end{array}$ & & & \\
\hline 7- & $\begin{array}{l}\text { The club seeks to establish academies in some Arab } \\
\text { Countries }\end{array}$ & & & \\
\hline 8- & $\begin{array}{l}\text { The club faces the social challenges due to changing } \\
\text { conditions (social-economic-political) }\end{array}$ & & & \\
\hline 9- & $\begin{array}{l}\text { The club tries to create new demands on its products } \\
\text { (commodities - services) locally and internationally }\end{array}$ & & & \\
\hline $10-$ & $\begin{array}{l}\text { The club tries to fix the marketing problems that may } \\
\text { emerge }\end{array}$ & & & \\
\hline $11-$ & The club tries to increase its financial resources & & & \\
\hline $12-$ & $\begin{array}{l}\text { The club tries to establish a well-recognized position } \\
\text { on the local, Arab and international levels }\end{array}$ & & & \\
\hline $13-$ & $\begin{array}{l}\text { The club tries to gain a competitive advantage on the } \\
\text { local, Arab and international levels }\end{array}$ & & & \\
\hline
\end{tabular}


Third Axis: Creative Product:

\begin{tabular}{|c|c|c|c|c|}
\hline No. & Item & Agree & Somehow & Disagree \\
\hline $1-$ & The club considers quality standards in its products & & & \\
\hline $2-$ & The club delivers the product in an attractive shape & & & \\
\hline $3-$ & $\begin{array}{l}\text { The club can sustain expanding production in case of } \\
\text { increased demands }\end{array}$ & & & \\
\hline 4- & $\begin{array}{l}\text { The club can deliver the product on a suitable level } \\
\text { without bearing extra costs }\end{array}$ & & & \\
\hline $5-$ & $\begin{array}{l}\text { The club competes with other clubs providing the same } \\
\text { products }\end{array}$ & & & \\
\hline 6- & The club tries to spread its products in various markets & & & \\
\hline 7- & $\begin{array}{l}\text { The club uses creative marketing tools to make quick } \\
\text { improvements on its current products }\end{array}$ & & & \\
\hline 8- & $\begin{array}{l}\text { The club considers qualities, features and attractiveness } \\
\text { of products to attract more customers }\end{array}$ & & & \\
\hline 9- & The club improves its current products & & & \\
\hline $10-$ & $\begin{array}{l}\text { The club tries to provide current customers with new } \\
\text { products (commodity }- \text { service) using creative } \\
\text { marketing }\end{array}$ & & & \\
\hline $11-$ & $\begin{array}{l}\text { The club tries to provide new customers with new } \\
\text { products (commodity - service) using traditional } \\
\text { marketing }\end{array}$ & & & \\
\hline $12-$ & $\begin{array}{l}\text { The club tries to provide new customers with products } \\
\text { (commodity - service) using creative marketing }\end{array}$ & & & \\
\hline $13-$ & $\begin{array}{l}\text { The club has a perspective about the life span of each } \\
\text { of its products }\end{array}$ & & & \\
\hline $14-$ & $\begin{array}{l}\text { The club assures continuous improvements for its } \\
\text { products }\end{array}$ & & & \\
\hline $15-$ & $\begin{array}{l}\text { The club tests its new products for the satisfaction of } \\
\text { customers }\end{array}$ & & & \\
\hline $16-$ & The club tries to open new markets for its products & & & \\
\hline $17-$ & $\begin{array}{l}\text { The club uses creative marketing to gain new ideas for } \\
\text { products }\end{array}$ & & & \\
\hline
\end{tabular}


Fourth Axis: Creative Delivery:

\begin{tabular}{|c|c|c|c|c|}
\hline No. & Item & Agree & Somehow & Disagree \\
\hline 1- & $\begin{array}{l}\text { The club improves delivery skills for its employees } \\
\text { during contact with customers }\end{array}$ & & & \\
\hline $2-$ & $\begin{array}{l}\text { Marketing department at the club performs periodical } \\
\text { research studies at delivery sites }\end{array}$ & & & \\
\hline 3- & The club depends on direct delivery & & & \\
\hline 4- & $\begin{array}{l}\text { The club is interested in distinct at attractive features of } \\
\text { the product to attract customers }\end{array}$ & & & \\
\hline $5-$ & The club uses modern technology in delivery & & & \\
\hline $6-$ & $\begin{array}{l}\text { Using modern technology in marketing and delivery } \\
\text { reduces the delivery timeframe }\end{array}$ & & & \\
\hline $7-$ & The club opens new delivery posts for its products & & & \\
\hline $8-$ & $\begin{array}{l}\text { The club is interested in mechanical sales for its } \\
\text { products }\end{array}$ & & & \\
\hline 9- & The club is interested in e-marketing & & & \\
\hline $10-$ & $\begin{array}{l}\text { The club distributes its products in other organizations' } \\
\text { markets (universities - schools - hotels) }\end{array}$ & & & \\
\hline $11-$ & The club is interested in direct distribution of products & & & \\
\hline $12-$ & $\begin{array}{l}\text { The club is interested in exporting its products with its } \\
\text { trade mark }\end{array}$ & & & \\
\hline $13-$ & $\begin{array}{l}\text { The club is interested in creativity in delivering } \\
\text { products }\end{array}$ & & & \\
\hline $14-$ & $\begin{array}{l}\text { The club uses creative methods for transporting } \\
\text { products }\end{array}$ & & & \\
\hline
\end{tabular}


Fifth Axis: Creative Promotion:

\begin{tabular}{l|l|l|l|l}
\hline No. & \multicolumn{1}{|c|}{ Item } & Agree & Somehow & Disagree \\
\hline $1-$ & The club uses creative promotion methods & & & \\
\hline $2-$ & $\begin{array}{l}\text { The club depends on promotion ideas of the marketing } \\
\text { department instead of using external ideas }\end{array}$ & & & \\
\hline $3-$ & $\begin{array}{l}\text { The club uses the internet (e-promotion) for promoting } \\
\text { its products }\end{array}$ & $\begin{array}{l}\text { The club is interested in continuous development of } \\
\text { marketing personnel skills }\end{array}$ & & \\
\hline 4- & The club depends on creative advertising & & \\
\hline $6-$ & $\begin{array}{l}\text { The club delivers promotion messages about products } \\
\text { via text messages }\end{array}$ & & \\
\hline $7-$ & The club uses innovative methods for activating sales & & \\
\hline $8-$ & The club uses new advertising enhancers & & \\
\hline $9-$ & $\begin{array}{l}\text { The club uses various events 9athletic - cultural - } \\
\text { artistic }- \text { social) to promote its products }\end{array}$ & & \\
\hline $10-$ & The club uses new and creative advertising methods & & & \\
\hline $11-$ & $\begin{array}{l}\text { The club works on opening new franchise in various } \\
\text { places }\end{array}$ & & & \\
\hline $12-$ & The club works on opening academies all over Egypt & & & \\
\hline
\end{tabular}


Sixth Axis: Creative Pricing:

\begin{tabular}{|c|c|c|c|c|}
\hline No. & Item & Agree & Somehow & Disagree \\
\hline $1-$ & $\begin{array}{l}\text { Current pricing policies effectively contributes in } \\
\text { convincing customers with products }\end{array}$ & & & \\
\hline $2-$ & The club has principles for pricing policies & & & \\
\hline 3- & Product price is suitable for its customer & & & \\
\hline 4- & $\begin{array}{l}\text { The club uses the right price for sustaining the product } \\
\text { existence in the market }\end{array}$ & & & \\
\hline $5-$ & $\begin{array}{l}\text { The club uses flexible pricing policy to face severe } \\
\text { changes in demand }\end{array}$ & & & \\
\hline $6-$ & When price is increased it is justifiable & & & \\
\hline 7- & $\begin{array}{l}\text { Prices are specified according to real cost and real price } \\
\text { of the product }\end{array}$ & & & \\
\hline 8- & $\begin{array}{l}\text { The product price is not affected by the reputation of } \\
\text { the deliverer }\end{array}$ & & & \\
\hline 9- & $\begin{array}{l}\text { The club specifies prices disregarding the related prices } \\
\text { of competitors }\end{array}$ & & & \\
\hline $10-$ & $\begin{array}{l}\text { Marketing department regularly seeks creative pricing } \\
\text { methods }\end{array}$ & & & \\
\hline $11-$ & Pricing problems are faced via creative strategy & & & \\
\hline $12-$ & Creative discounts are given to members & & & \\
\hline $13-$ & $\begin{array}{l}\text { The club adopts new ideas to decrease the product } \\
\text { costs }\end{array}$ & & & \\
\hline $14-$ & $\begin{array}{l}\text { The product can be replaced or returned in case of } \\
\text { customer dissatisfaction }\end{array}$ & & & \\
\hline $15-$ & $\begin{array}{l}\text { Creative pricing policies are used every once and while } \\
\text { due to improvements }\end{array}$ & & & \\
\hline $16-$ & $\begin{array}{l}\text { The club is interested in price competition with other } \\
\text { clubs }\end{array}$ & & & \\
\hline $17-$ & $\begin{array}{l}\text { The club uses creative pricing methods like pricing its } \\
\text { service units }\end{array}$ & & & \\
\hline $18-$ & $\begin{array}{l}\text { The club uses creative pricing methods like pricing its } \\
\text { service units (group discounts) }\end{array}$ & & & \\
\hline
\end{tabular}


Seventh Axis: Creative Communication:

\begin{tabular}{|c|c|c|c|c|}
\hline No. & Item & Agree & Somehow & Disagree \\
\hline $1-$ & $\begin{array}{l}\text { The club monitors service improvements in local } \\
\text { competing clubs }\end{array}$ & & & \\
\hline $2-$ & $\begin{array}{l}\text { The club monitors service improvements in } \\
\text { international competing clubs }\end{array}$ & & & \\
\hline $3-$ & $\begin{array}{l}\text { The club considers all creative recommendations of its } \\
\text { members and works on them }\end{array}$ & & & \\
\hline 4- & $\begin{array}{l}\text { The club follows media reports about potential risks of } \\
\text { similar products }\end{array}$ & & & \\
\hline $5-$ & The club has an information bank & & & \\
\hline $6-$ & $\begin{array}{l}\text { Employees can easily introduce their ideas to the } \\
\text { administration }\end{array}$ & & & \\
\hline 7- & $\begin{array}{l}\text { Members can easily introduce their ideas to the } \\
\text { administration }\end{array}$ & & & \\
\hline 8- & $\begin{array}{l}\text { Communication between marketing department and } \\
\text { other departments is effective }\end{array}$ & & & \\
\hline 9- & $\begin{array}{l}\text { The club contacts external research institutes to gain } \\
\text { creative marketing ideas }\end{array}$ & & & \\
\hline $10-$ & $\begin{array}{l}\text { The club uses research results to improve marketing } \\
\text { practices }\end{array}$ & & & \\
\hline $11-$ & $\begin{array}{l}\text { The club is interested in attending conferences and } \\
\text { seminars about sports marketing }\end{array}$ & & & \\
\hline $12-$ & $\begin{array}{l}\text { The club uses successful international experiences in } \\
\text { the field of creative marketing }\end{array}$ & & & \\
\hline
\end{tabular}


Eighth Axis: The role of higher administration in Supporting Creative Marketing:

\begin{tabular}{l|l|l|l|l}
\hline No. & \multicolumn{1}{|c|}{ Item } & Agree & Somehow & Disagree \\
\hline $1-$ & $\begin{array}{l}\text { Higher administration is interested in studying new } \\
\text { ideas about creative marketing }\end{array}$ & & \\
\hline $2-$ & $\begin{array}{l}\text { Higher administration is committed to support creative } \\
\text { marketing }\end{array}$ & $\begin{array}{l}\text { Higher administration considers planning creative } \\
\text { marketing inside the club's strategy }\end{array}$ & & \\
\hline $3-$ & $\begin{array}{l}\text { Higher administration encourages other administrative } \\
\text { levels to introduce and discuss new marketing ideas }\end{array}$ & & \\
\hline $5-$ & The club's guide reflects creativity and innovation & & \\
\hline $6-$ & The club provides monetary awards for creative ideas & & \\
\hline $7-$ & The club provides emotional awards for creative ideas & & & \\
\hline $8-$ & $\begin{array}{l}\text { The club depends on innovation and creativity in } \\
\text { evaluating its employees }\end{array}$ & $\begin{array}{l}\text { (n) professional development } \\
\text { opportunities for marketing personnel }\end{array}$ & & \\
\hline $9-$ & $\begin{array}{l}\text { Structural organization of creative marketing takes the } \\
\text { form of: } \\
10 / 1 \text { an independent department } \\
10 / 2 \text { a permanent committee } \\
10 / 3 \text { a unit in marketing department } \\
10 / 4 \text { an independent committee } \\
10 / 5 \text { one person responsible for creative marketing } \\
10 / 6 \text { a team for creative marketing }\end{array}$ & & & \\
\hline
\end{tabular}


Ninth Axis: Creative Marketing for Competitive Advantage:

\begin{tabular}{|c|c|c|c|c|}
\hline No. & Item & Agree & Somehow & Disagree \\
\hline $1-$ & $\begin{array}{l}\text { Competitive advantage means the clubs can outperform } \\
\text { its competitors in providing services }\end{array}$ & & & \\
\hline $2-$ & $\begin{array}{l}\text { Competitive advantage means the club is distinguished } \\
\text { from its competitors }\end{array}$ & & & \\
\hline $3-$ & $\begin{array}{l}\text { Competitive advantage means the club is able to } \\
\text { increase its resources }\end{array}$ & & & \\
\hline 4- & $\begin{array}{l}\text { The club can attain competitive advantage through } \\
\text { decreasing service costs }\end{array}$ & & & \\
\hline $5-$ & $\begin{array}{l}\text { Competitive advantage means finding a unique feature } \\
\text { for the club over other competitors }\end{array}$ & & & \\
\hline $6-$ & $\begin{array}{l}\text { Competitive advantage means finding new services that } \\
\text { are more efficient than the competitors' }\end{array}$ & & & \\
\hline 7- & $\begin{array}{l}\text { Competitive advantage means finding new methods to } \\
\text { win the competition }\end{array}$ & & & \\
\hline $8-$ & $\begin{array}{l}\text { The club can attain competitive advantage through } \\
\text { distinct services }\end{array}$ & & & \\
\hline 9- & $\begin{array}{l}\text { The club seeks competitive advantage though applying } \\
\text { strategic thinking }\end{array}$ & & & \\
\hline $10-$ & $\begin{array}{l}\text { Competitive advantage makes the club unique and } \\
\text { distinct among competitors }\end{array}$ & & & \\
\hline $11-$ & The club seeks a sustainable competitive advantage & & & \\
\hline $12-$ & $\begin{array}{l}\text { Competitive advantage should be renewable according } \\
\text { to external environment requirements }\end{array}$ & & & \\
\hline $13-$ & $\begin{array}{l}\text { Competitive advantage should be renewable according } \\
\text { to the club's internal resources }\end{array}$ & & & \\
\hline $14-$ & $\begin{array}{l}\text { Competitive advantage should be balanced with } \\
\text { objectives and results desired at the short and long run }\end{array}$ & & & \\
\hline $15-$ & $\begin{array}{l}\text { Knowledge is the most valuable resource to create } \\
\text { competitive advantage }\end{array}$ & & & \\
\hline $16-$ & The club attains competitive advantage via creativity & & & \\
\hline
\end{tabular}

